\title{
Photochemical Degradation of Pyrazosulfuron-Ethyl in Aqueous Solution
}

\author{
Yanhui Wang, ${ }^{a, b}$ Liangwei Du ${ }^{\#, a}$ and Lianyang Bai ${ }^{*, \#, b, c}$ \\ ${ }^{a}$ College of Chemistry and Chemical Engineering, Guangxi University, \\ 530004 Nanning, Guangxi, People's Republic of China \\ ${ }^{b}$ Department of Pesticide Science, Hunan Agricultural University, \\ 410128 Changsha, Hunan, People's Republic of China \\ ${ }^{c}$ Hunan Institute of Humanities, Science and Technology, \\ 417000 Loudi, Hunan, People's Republic of China
}

\begin{abstract}
Este trabalho descreve o comportamento fotoquímico do pirazosulfuronato de etila em soluções aquosas. A fotodegradação do pirazosulfuronato de etila foi investigada pela primeira vez em dois comprimentos de onda de irradiação diferentes e valores de $\mathrm{pH}$ variando de 2,00 a 10,00. Os resultados mostram que a taxa de fotodegradação foi mais rápida em meio ácido do que em meio básico, quando pyrazosulfuron-etil estava na forma neutra. Os tempos de meia-vida do pirazosulfuronato de etila sob luz ultravioleta e luz solar simulada foram 27,17 e 153,33 min, respectivamente. As reações seguiram cinética de primeira ordem. As rotas de degradação foram propostas de acordo com os resultados de identificação dos fotoprodutos: clivagens carbono-enxofre e nitrogênio-enxofre e fotohidrólise da ponte de sulfonilureia. Concluiu-se que comportamentos de fotodegradação podem ocorrer dentro da família de sulfonilureia, dependendo dos valores de pH da solução aquosa e dos comprimentos de onda de irradiação.
\end{abstract}

This report describes photochemical behaviors of pyrazosulfuron-ethyl in aqueous solution. The photodegradation of pyrazosulfuron-ethyl for the first time was investigated in aqueous solution at two different irradiation wavelengths and $\mathrm{pH}$ values ranging from 2.00 to 10.00 . Results show that the rate of photodegradation was faster in acidic medium than that in basic medium, when pyrazosulfuron-ethyl was in neutral form. The half-lives of pyrazosulfuron-ethyl under ultra-violet light and simulated sunlight were found to be 27.17 and $153.33 \mathrm{~min}$, respectively. The reactions followed first-order kinetics. The degradation pathways were proposed according to the identification results of photoproducts: carbon-sulfur and nitrogen-sulfur cleavages and photohydrolysis of the sulfonylurea bridge. It was concluded that photodegradation behaviors can occur within the sulfonylurea family, depending on the $\mathrm{pH}$ values of aqueous solution and the irradiation wavelengths.

Keywords: sulfonylureas, pyrazosulfuron-ethyl, photodegradation

\section{Introduction}

Sulfonylurea herbicides, discovered in the middle of the 1970's, have been widely used with a dramatic increase due to their low application rates (2-100 $\left.\mathrm{g} \mathrm{ha}^{-1}\right)$, good crop selectivity and very low animal toxicity. ${ }^{1-3}$ Their mode of action consists of the inhibition of acetolactate synthase (ALS), which is a key enzyme in the biosynthesis of the branched-chain amino acids such as valine, leucine and

*e-mail: lianyangbai@163.com

"Liangwei Du and Lianyang Bai contributed equally to this manuscript. isoleucine. ${ }^{1,4}$ The main abiotic degradation pathway of sulfonylurea herbicides is hydrolysis, but several works suggest that photodegradation is an alternative pathway to chemical hydrolysis. ${ }^{5-13}$ Indeed, these compounds were hydrolyzed more quickly in acidic than neutral or weakly basic $\mathrm{pH}$ value. Therefore, it is suggested that photodegradation become an important pathway at neutral $\mathrm{pH}$. In addition, it is known that photodegradation processes can accelerate chemical hydrolysis (photoassisted reaction) or form new products.

Pyrazosulfuron-ethyl (ethyl5-(4,6-dimethoxypyrimidin-2-ylcarbamoylsulfamoyl)-1-methylpyrazole- 
4-carboxylate) is a postemergence sulfonylurea herbicide for the control of annual and perennial grasses and broad-leaved weeds in rice production. The molecular structure of pyrazosulfuron-ethyl is presented in Figure 1. Several studies have indicated that pyrazosulfuron-ethyl has favorable toxicological and environmental fate characteristics. ${ }^{14,15}$ Similar to other sulfonylurea herbicides, degradation mechanisms for pyrazosulfuron-ethyl in rice paddies focus on microbial metabolism and chemical hydrolysis. ${ }^{15-17}$ However, no information was published on the photodegradation of pyrazosulfuron-ethyl in aqueous solution. The study on photodegradation in aqueous solution can be helpful to understand the pyrazosulfuron-ethyl behavior in the environment.

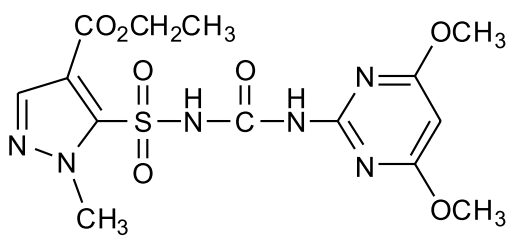

Figure 1. The molecular structure of pyrazosulfuron-ethyl.

This work reports the influence of $\mathrm{pH}$ value and irradiation wavelength on the photochemical behavior of pyrazosulfuron-ethyl. The main photoproducts were identified and a photoreaction pathway is proposed.

\section{Experimental}

\section{Material and apparatus}

Pyrazosulfuron-ethyl (98\% purity) was purchased from Dr. Ehrenstorfer GmbH (Augsburg, Germany). The standard chemical of photoproduct 1 (2-amino4,6-dimethoxypyrimidine) was supplied by Jiansu Institute of Ecomones Co., Ltd. (P. R. China). Methanol and acetonitrile of high performance liquid chromatography (HPLC) grade (Fisher Scientific Company, USA) were used without further purification. The water used for chromatography mobile phase and buffer preparation was purified with Millipore water system.

UV-Vis absorption and fluorescence spectra were recorded using a Shimadzu 2450 UV-Vis spectrophotometer and Perkin Elmer LS-55 spectrofluorometer, respectively. Kinetics was measured by high performance liquid chromatography with UV detector (HPLC-UV). The photodegradation products were identified using HPLC-UV, liquid chromatography-mass spectrometry (LC-MS) and gas chromatography-mass spectrometry (GC-MS) analyses.

\section{Photodegradation experiments}

In photolysis experiment, photodegradation of pyrazosulfuron-ethyl was carried out in water at different $\mathrm{pH}$ values and wavelengths. The photodegradation of the samples with the initial concentration of $20 \mathrm{mg} \mathrm{L}^{-1}$ was carried out in quartz cylindrical tubes $(50 \mathrm{~mL})$ using a low pressure mercury lamp emitting at $254 \mathrm{~nm}(25 \mathrm{~W})$ and a water-cooled filter with an optical window of $8 \mathrm{~cm}^{2}$ area. For irradiation at $\geq 290 \mathrm{~nm}$, a medium pressure mercury lamp $(125 \mathrm{~W})$ and borosilicate tubes were used. Temperature was controlled at $28 \pm 3{ }^{\circ} \mathrm{C}$. At various time intervals, samples were withdrawn in triplicate and analyzed by HPLC.

\section{HPLC analysis}

HPLC analyses were performed with a Waters 600 equipped with UV detector and autosampler. The column was Agilent Zorbax Eclipse $\mathrm{XDB}^{-\mathrm{C}_{18}}(250 \times 4.6 \mathrm{~mm}$ i.d.;

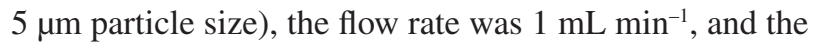
injection volume was $20 \mu \mathrm{L}$. For kinetic studies, the mobile phase was a 75:25 mixture of methanol-0.2\% aqueous acetic acid ( $\mathrm{pH} 2.80$ ). For the analyses of photoproducts, a mobile phase gradient was $0.2 \%$ acetic acid in water (i) and acetonitrile (ii), starting with $40 \%$ (i) for $5 \mathrm{~min}$, changing to $20 \%$ over $5 \mathrm{~min}$, and then remaining constant for the last $5 \mathrm{~min}$.

Degradation kinetics was described using a first-order reaction model: $C_{t}=C_{0} \times e^{-k t}$, where $C_{0}\left(\mathrm{mg} \mathrm{kg}^{-1}\right)$ is the initial concentration in soil, $C_{t}\left(\mathrm{mg} \mathrm{kg}^{-1}\right)$ is the concentration at time $t$ (min) and $k\left(\mathrm{~min}^{-1}\right)$ is the rate constant. The half-life was calculated as $t_{1 / 2}=\ln (2) / k$.

\section{LC-MS analysis}

The identification of photoproducts was performed with Agilent Technologies 1100 Series LC-MSD Trap. The column was $\mathrm{XDB}-\mathrm{C}_{18}(150 \times 4.6 \mathrm{~mm}$ i.d.; $1.7 \mu \mathrm{m})$. The mass spectrometer was equipped with an ESI (electrospray ionization) source and operated in the positive and negative polarity mode. The ES-MS interface was operated under the conditions of a gas temperature of $350^{\circ} \mathrm{C}$ and a drying gas flow of $800 \mathrm{~L} \mathrm{~h}^{-1}$. The nebulizer nitrogen gas pressure was 35 psi, while the capillary voltage was set to $3000 \mathrm{~V}$. Full scans were obtained by scanning from $\mathrm{m} / \mathrm{z} 50$ to 600 .

\section{GC-MS analysis}

The analyses were performed on an Agilent 7890A/5957C equipped with a capillary HP-5MS (30 $\mathrm{m} \times 0.25 \mathrm{~mm}$ i.d.; $0.25 \mu \mathrm{m}$ film). The temperature 
program was from 40 to $180{ }^{\circ} \mathrm{C}$ at $4{ }^{\circ} \mathrm{C} \mathrm{min}^{-1}$, then from 180 to $250^{\circ} \mathrm{C}$ at $10^{\circ} \mathrm{C} \mathrm{min}^{-1}$. Analyses were performed in splitless mode and the injection temperature was $220^{\circ} \mathrm{C}$. The transfer line was conditioned at $250^{\circ} \mathrm{C}$, the ion source operated at $70 \mathrm{eV}$ and $250{ }^{\circ} \mathrm{C}$, the acquisition was from $\mathrm{m} / \mathrm{z}, 50$ to 500 .

\section{Results and Discussion}

\section{Absorption spectrum of pyrazosulfuron-ethyl}

Like other sulfonylureas herbicides, pyrazosulfuronethyl is a bichromophoric compound whose pyrazole ring and pyrimidine were linked through a sulfonylurea bridge. The UV spectrum of pyrazosulfuron-ethyl was measured in water at $\mathrm{pH} 6.50$ (Figure 2). The molecule presented two absorption maxima below $290 \mathrm{~nm}$ (195 and $241 \mathrm{~nm}$ ), but also a measurable absorption tail up to $300 \mathrm{~nm}$. According to an EC (94/37/CE) directive, phototransformation must be taken into account if the molar extinction coefficient $\varepsilon>10 \mathrm{~L} \mathrm{~mol}^{-1} \mathrm{~cm}^{-1}$ at $\lambda \geq 290 \mathrm{~nm}$. For pyrazosulfuron-ethyl, $\varepsilon=1200 \mathrm{~L} \mathrm{~mol}^{-1} \mathrm{~cm}^{-1}$ at wavelength of $290 \mathrm{~nm}$, meaning that the photolytic degradation pathway should not be neglected.

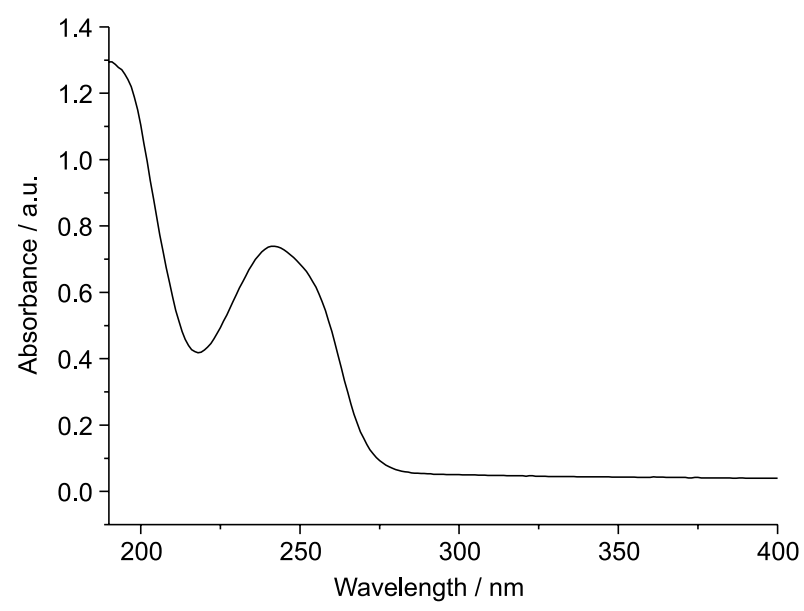

Figure 2. UV spectrum of pyrazosulfuron-ethyl in aqueous solution.

\section{Kinetics of pyrazosulfuron-ethyl}

The photodegradation of pyrazosulfuron-ethyl was investigated in aqueous solution. The influence of $\mathrm{pH}$ value and irradiation wavelength was evaluated in this section. The performed $\mathrm{pH}$ values ranged from 2.00 to 10.00 . The irradiation wavelengths were $254 \mathrm{~nm}$ from UV light and above $290 \mathrm{~nm}$ from simulated sunlight, respectively.

Since the chemical stability of sulfonylureas in aqueous solution is markedly influenced by $\mathrm{pH},{ }^{17-21}$ the
$\mathrm{pH}$ values of aqueous solution could have effect on the photodegradation of pyrazosulfuron-ethyl. This study was carried out at different $\mathrm{pH}(2.00-10.00)$ under the conditions of irradiation at wavelength of $254 \mathrm{~nm}$. Meanwhile, the illumination time of photodegradation were less than $180 \mathrm{~min}$ in order to avoid the side effect of chemical hydrolysis. The photodegradation of pyrazosulfuron-ethyl at different $\mathrm{pH}$ followed first-order kinetic with high $\mathrm{R}^{2}$ values (correlation coefficient, $\geq 0.9217$ ). The evolution of pyrazosulfuron-ethyl kinetic constants as a function of $\mathrm{pH}$ is represented in Figure 3. The rate constants and half-lives for the photolysis of pyrazosulfuron-ethyl in different $\mathrm{pH}$ are presented in Table 1. From these results, the kinetic constants of pyrazosulfuron-ethyl obviously increase with the decrease of $\mathrm{pH}$, ranging from $0.0153 \mathrm{~min}^{-1}$ at $\mathrm{pH} 10.00$ to $0.0395 \mathrm{~min}^{-1}$ at $\mathrm{pH} 2.00$. The corresponding half-lives of pyrazosulfuron-ethyl decrease from 45.10 to $17.47 \mathrm{~min}$. The $\mathrm{pH}$ value-kinetics measurements showed that photodegradation was faster in acidic medium than that in basic medium, when pyrazosulfuron-ethyl was in neutral form. These results suggested that acid-base behavior of pyrazosulfuron-ethyl could have been involved in the photodegradation. Vulliet et al. ${ }^{12}$ also reported the same phenomenon about cinosulfuron, while photodegradation rate of triasulfuron is at a maximum at $\mathrm{pH}$ 4. Considering the $\mathrm{pH}$ of actual samples, the photolysis of pyrazosulfuron-ethyl in the following experiments was performed at $\mathrm{pH} 6.50$.

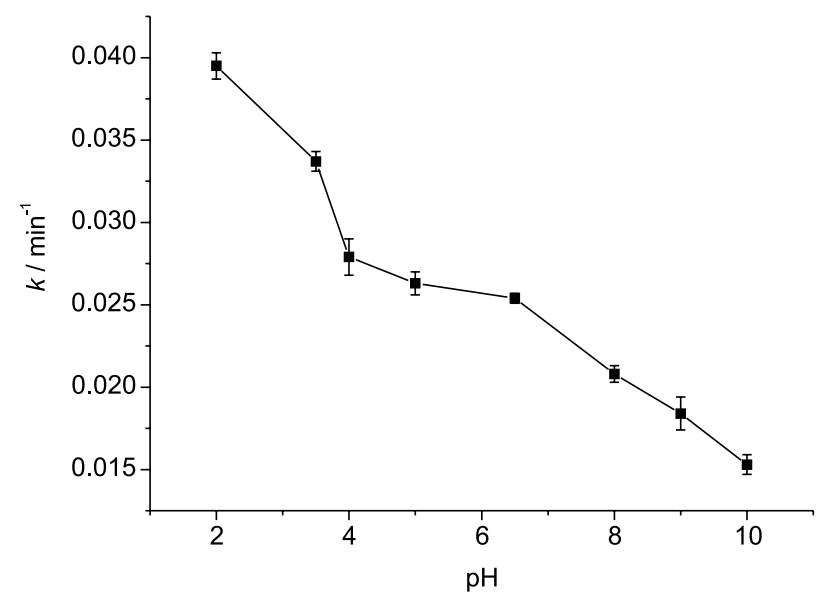

Figure 3. Evolution of of pyrazosulfuron-ethyl kinetic constants as a function of $\mathrm{pH}$ values.

In order to evaluate the influence of the wavelength on the photochemical behavior of pyrazosulfuron-ethyl, the present study evaluates the rate of photodegradation of pyrazosulfuron-ethyl in distilled water with the $\mathrm{pH}$ of 6.50 under UV light $(\lambda=254 \mathrm{~nm})$ and simulated sunlight $(\lambda \geq 290 \mathrm{~nm})$. The kinetic results of the photodegradation 
Table 1. Determination of rate constant $(k)$ and half-life $\left(t_{1 / 2}\right)$ for the photolysis of pyrazosulfuron-ethyl

\begin{tabular}{lccc}
\hline $\mathrm{pH}$ & $k / \mathrm{min}^{-1}$ & $t_{1 / 2} / \mathrm{min}$ & $\mathrm{R}^{2}$ \\
\hline 2.00 & 0.0395 & 17.47 & 0.9328 \\
3.50 & 0.0337 & 20.47 & 0.9437 \\
4.00 & 0.0279 & 24.73 & 0.9619 \\
5.00 & 0.0263 & 26.24 & 0.9527 \\
6.50 & 0.0254 & 27.17 & 0.9611 \\
8.00 & 0.0208 & 33.17 & 0.9217 \\
9.00 & 0.0184 & 37.50 & 0.9785 \\
10.00 & 0.0153 & 45.10 & 0.9544 \\
\hline
\end{tabular}

at different wavelengths were presented in Table 2, showing that wavelengths have a significant effect on the kinetics. The half-lives of pyrazosulfuron-ethyl under UV light and simulated sunlight were found to be 27.17 and $153.33 \mathrm{~min}$, respectively. The transformation of pyrazosulfuron-ethyl in aqueous solutions irradiated at $254 \mathrm{~nm}$ was significantly faster than at $\lambda \geq 290 \mathrm{~nm}$. This is mainly due to the weaker absorption of pyrazosulfuron-ethyl at the longer wavelength range. These results are in agreement with the data reported for other sulfonylureas..$^{9,12,22,23}$

Table 2. Photodegradation kinetics parameter of pyrazosulfuron-ethyl

\begin{tabular}{lcccc}
\hline Pyrazosulfuron-ethyl & $\lambda / \mathrm{nm}$ & $k / \mathrm{min}^{-1}$ & $t_{1 / 2} / \min$ & $\mathrm{R}^{2}$ \\
\hline Distilled water & 254 & 0.0254 & 27.17 & 0.9611 \\
Distilled water & $\geq 290$ & 0.0045 & 153.33 & 0.9657 \\
\hline
\end{tabular}

\section{Photoproduct identification}

The photoproducts were identified by HPLC-UV, GC-MS and LC-MS. From HPLC-UV chromatograms (Figure S1 in the Supplementary Information (SI) section), the main photoproducts under two irradiation wavelengths have characteristic peaks at the same retention time $\left(t_{\mathrm{r}}\right)$. In this experiment, it was only identified the photoproducts under the conditions of irradiation at UV light. Mass spectrometry data of the irradiated solutions are given in Table 3 and Figures S2 and S3 (in the SI section).

Product 1 in GC-MS has a retention time of $22.5 \mathrm{~min}$ and m/z (\%): $154\left(\mathrm{M}^{+}, 100\right), 139$ (9), 125 (20), 109 (18).
Meanwhile, the product 1 was confirmed by the same retention time with standard chemical in HPLC analysis (shown in Figure S1 in the SI section). It was tentatively identified as 2-amino-4,6-dimethoxypyrimidine, which results from the photohydrolysis of the sulfonylurea link, a typical degradation pathway of sulfonylurea herbicides under irradiation. The compound was also detected as a hydrolysis product for pyrazosulfuron-ethyl ${ }^{17}$ and other sulfonylureas with a pyrimidine ring, for example, azimsulfuron ${ }^{18}$ and rimsulfuron. ${ }^{11}$

The other photoproducts were identified by LC-MS and together with literature data. ${ }^{17,24}$ In positive mode, the mass spectrum of photoproduct 2 showed a prominent protonated molecular ion at $\mathrm{m} / \mathrm{z} 308.1[\mathrm{M}+\mathrm{H}]^{+}$and characteristic fragment ion peaks at $m / z$ 289.0, 280.0, 262.0 and 232.9. $[\mathrm{M}-\mathrm{H}]^{-}$ion of this compound is 306.1 in negative mode. This photoproduct results from the contraction of the sulfonylurea bridge in solutions and is also detected as a hydrolysis product. ${ }^{17}$ This contraction mechanism is suggested to proceed through an intramolecular $\mathrm{S}_{\mathrm{N}} \mathrm{Ar}$ reaction..$^{25}$

The mass spectrum of photoproduct 3 showed a molecular ion peak at $m / z$ 199.8 $[\mathrm{M}+\mathrm{H}]^{+}$with fragment ion peaks at $m / z 167.8,155.9$ and 135.8. [M $-\mathrm{H}]^{-}$ ion of this compound is 197.9 in negative mode. According to mass spectral data and fragment patterns, the photoproduct was tentatively identified as 2-ureido4,6-dimetoxypyrimidine and photodegradation pathway was nitrogen-sulfur cleavage. This photoproduct was also found as a photodegradation product for azimsulfuron ${ }^{9}$ and bensulphuron methyl. ${ }^{24}$ Mass spectrometry results do not allow us a certain identification of other photoproducts originating after irradiation under UV light.

According to photoproducts and literature data, ${ }^{12,13,22,24,26}$ a tentative pathway for the photolysis of pyrazosulfuron-ethyl in aqueous solution is proposed in Figure 4. Three different pathways are proposed: cleavage of the sulfonylurea bridge to give photoproduct 1 , an intramolecular $\mathrm{S}_{\mathrm{N}} \mathrm{Ar}$ reaction leading to photoproduct 2 and photodesulfonylation which proceeds by a homolitic nitrogen-sulfur cleavage, yielding photoproduct 3. However, the theoretical photoproduct from carbon-sulfur cleavage (4,6-dimetoxypyrimidine-

Table 3. LC-ESI-MS data of pyrazosulfuron-ethyl and its photodegradation products, in which $t_{\mathrm{r}}$ stands for retention time

\begin{tabular}{|c|c|c|c|}
\hline Product & $t_{\mathrm{r}} / \min$ & Mass, $m / z$ & $\mathrm{MS}^{2}, m / z$ \\
\hline Pyrazosulfuron-ethyl & 9.3 & $413.0\left(\mathrm{ESI}^{-}\right)$ & $306.1,231.9,153.8$ \\
\hline 1 & 4.2 & $155.9\left(\mathrm{ESI}^{+}\right)$ & $135.8,126.8,109.8,99.9$ \\
\hline 2 & 6.7 & $308.1\left(\mathrm{ESI}^{+}\right)$ & $289.0,280.0,262.0,232.9$ \\
\hline 3 & 5.8 & $199.8\left(\mathrm{ESI}^{+}\right)$ & $167.8,155.9,135.8$ \\
\hline
\end{tabular}




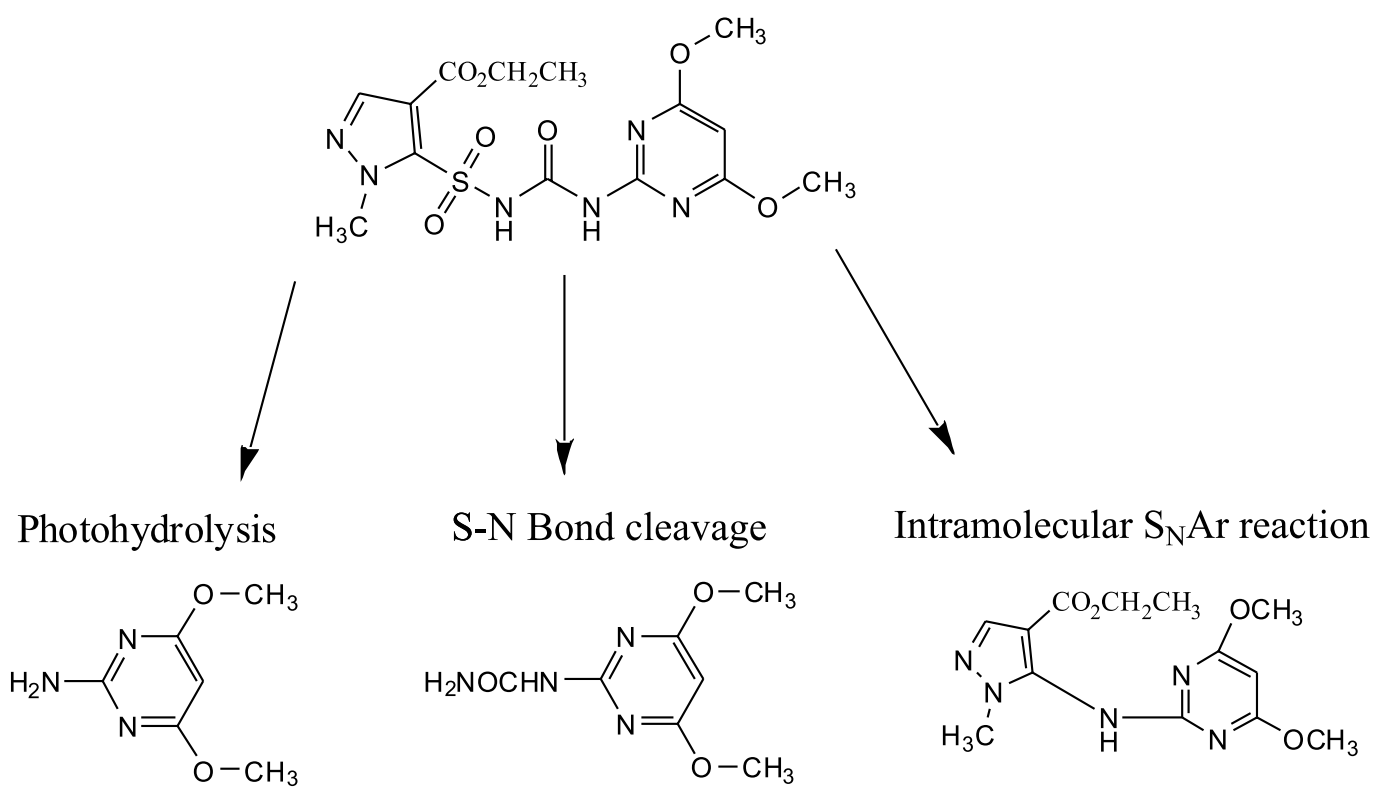

Figure 4. Hypothetical photodegradation pathway of pyrazosulfuron-ethyl in aqueous solution.

2-ylaminocarbonylsulphamic acid) was not found in this experiment. It is supposed that 4,6-dimetoxypyrimidine2-yl aminocarbonylsulphamic acid rapidly transformed to product 3 after only a few minutes of irradiation. According to the content of photoproducts, the N-S bond cleavage was considered as the main photochemical pathway in this experiment. This photodegadation pathway was also reported for some sulfonylureas herbicides by Weiss et al. ${ }^{27}$ and Caselli et al. ${ }^{6}$ The results are similar with data reported for other sulfonylureas degradation by light. ${ }^{12,22,24}$ However, carbon-sulfur cleavage is recognized as the main photochemical pathway for triasulfuron, primisulfuron, cinosulfuron and sulfometuron-methyl. ${ }^{13,23,28}$ These experimental evidences and theoretical predictions indicate an important effect of the substituent on the phenyl ring. The $o$-chloro, $p$-methyl and $p$-amino groups favour $\mathrm{N}-\mathrm{S}$ bond photocleavage, while the $o-\mathrm{OR}$ (-OR strands for alkoxy radical) substituent in cinosulfuron and triasulfuron leads to $\mathrm{C}-\mathrm{S}$ bond photocleavage. ${ }^{26}$

\section{Conclusion}

The photolysis studies on pyrazosulfuron-ethyl were carried out in aqueous solution at different irradiation wavelengths and $\mathrm{pH}$ values. It was find that photodegradation of pyrazosulfuron-ethyl was faster under UV light than simulated sunlight and was faster in acidic medium than basic medium. On the basis of the results obtained, it is possible to conclude that photodegradation behaviors can occur in pyrazosulfuron-ethyl, depending on the $\mathrm{pH}$ values of aqueous solution and the irradiation wavelengths.

\section{Supplementary Information}

Supplementary data are available free of charge at http://jbcs.sbq.org.br as PDF file.

\section{Acknowledgements}

This work was supported by National Natural Science Foundation of P. R. China (Grant No. 31171891) and Postgraduate Innovation Program of Hunan Province (Grant No. CX2011B288).

\section{References}

1. Blair, A. M.; Martin, T. D.; Pestic. Sci. 1988, 22, 195.

2. Brown, H. M.; Pestic. Sci. 1990, 29, 263.

3. Zhou, Q. Y.; Liu, W. P.; Zhang, Y. S.; Liu, K. K.; Pestic. Biochem. Physiol. 2008, 89, 89.

4. Beyer, E. M.; Duffy, M. J.; Hay, J. V.; Schlueter, D. D. In Herbicide Chemistry Degradation and Mode of Action; Kearney, P. C.; Kaufman, D. D., eds.; Marcel Dekker: New York, USA, 1988, p. 118-183.

5. Bhattacherjee, A. K.; Dureja, P.; Pestic. Sci. 1999, 55, 183.

6. Caselli, M.; Chemosphere 2005, 59, 1137.

7. Choudhury, P. P.; Dureja, P.; J. Agric. Food Chem. 1996, 44, 3379.

8. Harvey, J.; Dulka, J.; Anderson, J.; J. Agric. Food Chem. 1985, $33,590$.

9. Pinna, M. V.; Zema, M.; Gessa, C.; Pusino, A.; J. Agric. Food Chem. 2007, 55, 6659.

10. Scrano, L.; Bufo, S. A.; Perucci, P.; Meallier, P.; Mansour, M.; Pestic. Sci. 1999, 55, 955. 
11. Schneiders, G. E.; Koeppe, M. K.; Naidu, M. V.; Horme, P.; Brown, A. M.; Mucha, C. F.; J. Agric. Food Chem. 1993, 41, 2404.

12. Vulliet, E.; Emmelin, C.; Chovelon, J. M.; J. Photochem. Photobiol., A 2004, 163, 69.

13. Vulliet, E.; Emmelin, C.; Grenier-Loustalot, M. F.; Paisse, O.; Chovelon, J. M.; J. Agric. Food Chem. 2002, 50, 1081.

14. Ding, F.; Liu, W.; Zhang, X.; Wu, L. J.; Zhang, L.; Sun, Y.; Spectrochim. Acta, Part A 2010, 75, 1088.

15. Xu, J.; Li, X. S.; Xu, Y. J.; Qiu, L. H.; Pan, C. P.; Chemosphere 2009, 74, 682.

16. Wang, Y. H.; Du, L. W.; Chen, Y. X.; Liu, X. L.; Zhou, X. M.; Tan, H. H.; Bai, L. Y.; Zeng, D. Q.; Folia. Microbiol. 2012, 57, 139.

17. Zheng, W.; Yates, S. R.; Papiernik, S. K.; J. Agric. Food Chem. 2008, 56, 7367.

18. Boschin, G.; D’Agostina, A.; Antonioni, C.; Locati, D.; Arnoldi, A.; Chemosphere 2007, 68, 1312.

19. Brigante, M.; Emmelin, C.; Previtera, L.; Baudot, R.; Chovelon, J. M.; J. Agric. Food Chem. 2005, 53, 5347.
20. Saha, S.; Shrestha, G.; J. Agric. Food Chem. 2002, 50, 4572.

21. Sarmah, A. K.; Sabadie, J.; J. Agric. Food Chem. 2002, 50, 6253.

22. Morrica, P.; Fidente, P.; Seccia, S.; Biomed. Chromatogr. 2004, 18,450 .

23. Pusino, A.; Braschi, I.; Petretto, S.; Gessa, C.; Pestic. Sci. 1999, $55,479$.

24. Fidente, P.; Carpentiero, C.; Morrica, P.; Seccia, S.; Int. J. Environ. Anal. Chem. 2006, 86, 277.

25. Galeazzi, R.; Marucchini, C.; Orena, M.; Porzi, G.; Heterocycles 2000, 53, 2517.

26. Corminboeuf, C.; Carnal, F.; Weber, J.; Chovelon, J. M.; Chermette, H.; J. Phys. Chem. A 2003, 107, 10032.

27. Weiss, B.; Dürr, H.; Haas, H. J.; Angew. Chem., Int. Ed. Engl. 1980, 19, 648.

28. Braschi, I.; Pusino, A.; Gessa, C.; Bollag, J. M.; J. Agric. Food Chem. 2000, 48, 2565.

Submitted: May 10, 2012 Published online: February 7, 2013 